\title{
Ginger (Zingiber Officinale Rosc.) Productivity in Tree Based Agro Forestry System
}

\author{
Vardhan Pandey V*, Shukla S, Saxena J, Salman Khan and Kumar R \\ Forest Research Institute, India \\ Submission: April 10, 2018; Published: May 23, 2018 \\ "Corresponding author: Vijay Vardhan Pandey, Forest Research Institute, Dehradun, India, email: vijayvardhan1989@gmail.com
}

\begin{abstract}
Agroforestry system is a modern tool for sustainable land use and to increase production by growing vegetables under forest trees in some form of spatial arrangement or temporal sequence. Tree co-exists with the vegetable crops, their compatibility may be crucial to determining the success of this system. It was once more unambiguously proved that ginger is a scicophytic crop performing remarkably well under partial shade than the open field. It is vital to pinpoint that the enhancement in plant height was coupled with long internodes only, not for the number of internodes. It is to be muscularly weighed that the number of leaves per plant and the number of nodes per plant are hereditarily comparative to each other in case of any ginger variety. Ginger under poplar accumulates a large bulk of its final weight during the later months prior to reaching maturity, early harvests result in lower yields. Shade grown ginger remained greener and therefore, physiologically active for a longer time, despite having relatively lower essential oil and oleoresin concentrations compared to monoculture of ginger in open field. The cost-benefit ratio was high and the system also gave indirect benefits in erosion control and maintenance of soil fertility.
\end{abstract}

Keywords: Agroforestry system, ginger, poplar, productivity

\section{Introduction}

In India, Agriculture and Forestry have co-existed for many years in close proximity. Farmers from time immemorial have been growing useful tree species with agricultural crops, horticultural crops which used to supply food, fodder, fuel and small timber for himself and his livestock. Agroforestry systems of land use are not new to our rich heritage. The concept of Agri-Horti-Silvicultural combination of perennial tree and fruit species, vegetable species could profitably be adopted in both arable and non-arable marginal and sub-marginal lands. Highdensity multispecies systems besides providing higher income, also allow the farmers to meet the various needs. These systems utilize the soil from its best capability and generate higher biomass from the same piece of land without any loss of fertility. The idea behind planting vegetable crops as an intercrop with Silvi-plants is to obtain biomass production before these plants attain full growth, and later to obtain fodder or green manure material by frequent cutting and create thicker vegetation for better soil and water conservation.

Agroforestry system offers a good scope for more efficient use of land; water, other natural and human resources. The main advantages of this system would be:

a. Progressive land improvement by providing vegetation cover and brief to bring about soil and water conservation and production of organic material for the enrichment of soil. b. Recycling of plant nutrients is possible due to roots of perennial tree species penetrating deep into the soil and absorbing the plant nutrients and depositing on the soil surface through leaf litter.

c. Perennial tree species are photo-synthetically active throughout the year and hence produce large quantities of biomass.

d. Legumes plants may provide for fixation of atmospheric nitrogen and thereby enrich the site conditions.

e. Provide employment opportunities to the people.

Ginger is used throughout the world for flavoring in beverages, liqueurs, ice cream, candies, baked goods, curry powder blends, sauces, and various condiments. Ginger is also used in traditional medicine to treat several ailments including nausea, dyspepsia, motion sickness, mi-graine, and to reduce flatulence and colic. It is a spice or fresh herb for cooking. Early harvested young rhizomes are also used in pickles and confectionery.

Ginger is an herbaceous perennial, grown as an annual for its spicy underground rhizomes or stems. The plant has fibrous roots that emerge from the branched rhizomes. Closely grouped, unbranched, pseudo stems or aerial shoots are produced from the rhizomes. The pseudo stems reach a height of $50-120 \mathrm{~cm}$. The 
simple, lanceolate, and smooth leaves are alternate and about $25 \mathrm{~cm}$ long. The flowers are small, speckled, yellowish, each with a purple speckled lip and borne on a spike. Ginger is one of the earliest known oriental spices and is being cultivated in India both as a fresh vegetable and as a dried spice since time immemorial.

In Sub-tropical regions, ginger is often interplant in agroforestry systems, such as between rows of Populus, Ailanthus, Luceana etc. Ginger being moderately tolerant of shade is well adapted to agroforestry systems. In trees like Poplar, when the trees approach canopy closure, Ginger is planted in between the Poplar rows. Ginger is also an important foreign exchange earning crop. The processed products of ginger have high export value in the Middle East and some European countries.

\section{Status of Ginger Production in World}

World production for ginger in 2014 was 2156453 tons with area under cultivation 396724ha. Ginger is cultivated in Indian subcontinent, China, Japan, Indonesia, Australia, Nigeria and West Indies islands. India is the largest producer and consumer of ginger in the world. India, China, Nepal, Indonesia and Thailand accounts for $83 \%$ of the total ginger production of the world. Although India is the largest producer of the world, yet average productivity is highest in Fizi ie. $34521 \mathrm{Kg} / \mathrm{h}$. The largest ginger importers are the United Kingdom, the United States and Saudi Arabia. Ginger production in Nepal During 2008-09, increased to 178,988 tons of ginger and exported ginger worth Rs.1.37 billion (\$18.3 million US dollars) about 99 percent of total production to India [1]. Area and production of ginger in the world are shown in Table $1 \& 2$.

Table 1: The Top 5 Ginger Producing Countries.

\begin{tabular}{|c|c|c|c|c|c|}
\hline & Country & $\begin{array}{c}\text { Production 2014 } \\
\text { (Metric tonnes) }\end{array}$ & $\begin{array}{c}\text { Production 2010 } \\
\text { (Metric tonnes) }\end{array}$ & $\begin{array}{c}\text { Production 2005 } \\
\text { (Metric tonnes) }\end{array}$ & $\begin{array}{c}\text { Production 2000 } \\
\text { (Metric tonnes) }\end{array}$ \\
\hline 1 & India & 655000 & 385330 & 359000 & 235000 \\
\hline 2 & China & 450686 & 399864 & 286698 & 228056 \\
\hline 3 & Indonesia & 266145 & 107735 & 125827 & 115092 \\
\hline 4 & Nepal & 276150 & 210790 & 154200 & 74994 \\
\hline 5 & Thailand & 161404 & 172681 & 139048 & 134243 \\
\hline & & & & & \\
\hline
\end{tabular}

Table 2: Yearly harvested area, production and yield of Ginger in worldwide.

\begin{tabular}{|c|c|c|c|}
\hline Year & Area (ha) & Production (tonnes) & Yield (Kg/ha) \\
\hline 2000 & 302861 & 1025462 & 33859 \\
\hline 2001 & 312627 & 1119098 & 35797 \\
\hline 2002 & 329146 & 1179807 & 35844 \\
\hline 2003 & 339298 & 1250941 & 36868 \\
\hline 2004 & 336404 & 1232283 & 36631 \\
\hline 2005 & 361598 & 1368089 & 37835 \\
\hline 2006 & 415598 & 1472579 & 35433 \\
\hline 2007 & 282083 & 1581506 & 56065 \\
\hline 2008 & 276159 & 1596439 & 57809 \\
\hline 2009 & 279207 & 1643275 & 58855 \\
\hline 2010 & 268723 & 1691811 & 62957 \\
\hline 2011 & 307037 & 2337671 & 76136 \\
\hline 2013 & 363904 & 2421181 & 66533 \\
\hline
\end{tabular}

\section{National Scenario of Ginger Production}

India stands first in the production (655000 tones) of ginger and second in the area $(133,000$ hectares) under ginger cultivation in the world. Average productivity of ginger in India i.e. $49248 \mathrm{~kg} / \mathrm{ha}$ is slightly lower than the world's average (54356kg/ha). The crop exhibited an annual growth rate of 4.6 percent in the area, 7.4 percent in production and 2.7 percent in productivity in India.

Ginger is grown all over India but the finest quality ginger i.e., Cochin Ginger which has extensive demand in the world market comes from Kerala endowed as it is with a congenial climate and a rich earthy soil. This is the reason that Indian dry ginger is 
known as 'Cochin Ginger' (NUGC) \& 'Calicut Ginger' (NUGK) in the world market. Cochin ginger is considered one of the best ginger in the world.

India has a predominant position in ginger production contributing about 30 percent of the total world production. Ginger is cultivated throughout the India. However, states namely
Karnataka, Orissa, Assam, Meghalaya, Arunachal Pradesh and Gujarat together contribute 65percent to the country's total production. Assam tops the chart continuously with highest production (141441 tons) of ginger followed by West Bengal (129018tons) and Uttaranchal (109340tons) in the year 201516 [2] (Table 3).

Table 3: Last 10 years Area, Production and Yield of Ginger in India.

\begin{tabular}{|c|c|c|c|}
\hline Year & Area (ha) & Production (tonnes) & Yield (kg/ha) \\
\hline 2000 & 70000 & 235000 & 33571 \\
\hline 2001 & 70081 & 230000 & 32819 \\
\hline 2002 & 80469 & 260828 & 31769 \\
\hline 2003 & 88200 & 280200 & 35476 \\
\hline 2004 & 85100 & 301900 & 37671 \\
\hline 2005 & 95300 & 359000 & 35371 \\
\hline 2006 & 110600 & 391200 & 37078 \\
\hline 2007 & 106100 & 393400 & 37378 \\
\hline 2008 & 104360 & 390080 & 34987 \\
\hline 2010 & 108640 & 380100 & 35831 \\
\hline 2011 & 107540 & 385330 & 47082 \\
\hline 2012 & 149100 & 702000 & 48774 \\
\hline
\end{tabular}

Table 4:Top 10 Importers of Indian Ginger.

\begin{tabular}{|c|c|c|c|c|}
\hline \multirow{2}{*}{ Country } & \multicolumn{2}{|c|}{ Value (Rs lakh) } & \multicolumn{2}{c|}{ Quantity (million tonnes) } \\
\cline { 2 - 5 } & $\mathbf{2 0 1 3 - 1 4}$ & $\mathbf{2 0 1 4 - 1 5}$ & $\mathbf{2 0 1 3 - 1 4}$ & $\mathbf{2 0 1 4 - 1 5}$ \\
\hline USA & 2438.47 & 2673.02 & 1327.14 & 1137.86 \\
\hline Spain & 3235.76 & 4854.04 & 1782.5 & 2109.63 \\
\hline Saudi Arabia & 1160.6 & 2293.56 & 722.55 & 1457.52 \\
\hline Bangladesh & 2935.61 & 4054.49 & 9231.48 & 5261.44 \\
\hline UK & 1427.34 & 1230.66 & 856.59 & 405.35 \\
\hline Morocco & 771.88 & 793.81 & 629.15 & 1616.53 \\
\hline UAE & 695.22 & 2203.94 & 295.95 & 401.89 \\
\hline Germany & 853.55 & 1230.5 & 3543.01 & 5142.75 \\
\hline Pakistan & 1911.71 & 3224 & 275.53 & 383.95 \\
\hline YAR & 543.66 & 805.12 & & \\
\hline
\end{tabular}

In India, ginger is effectively used as an intercrop with the multipurpose trees viz. Populus, Paulownia, Ailanthus, Coconut, Betelnut and Palms etc. In India, ginger yields were increased during intercropping compared to monoculture yields when intercropped with poplar where Poplar is planted with the spacing of $5 \mathrm{mx} 4 \mathrm{~m}$ and yields $196 \%$ more as compared to monoculture. However ginger yields were decreased when poplar trees were planted at very high densities, of $5 \mathrm{~m} \times 3 \mathrm{~m}$, resulting in over $53 \%$ shade [3]. In China, while the yields of some intercrops such as beans and corn were decreased in agroforestry systems with Paulownia elongata, ginger yields were $34 \%$ greater than in the ginger monocultures [4]. In the
Philippines, ginger has traditionally been intercropped with cash crops such as mung bean (Vigna radiata), sweet potato (Ipomoea batatas), cabbage (Brassica oleracea) and sweet corn (Zea mays) [5]. Ginger produced in India goes for domestic consumption and only a small quantity is exported. But in other producing countries domestic consumption is less and export is more. The global demand for Indian ginger is high on account of its lemony flavor. Garbled/ungarbled and bleached/unbleached variants occupy a predominant position in ginger export. Cochin ginger is popular and it fetches a premium price because of its superior quality. Country-wise export of Indian ginger is shown in Table 4. 


\section{Cultivation and Consumption}

In India ginger is produced in the states of Orissa, Kerala, Karnataka, Arunachal Pradesh, West Bengal, Sikkim and Madhya Pradesh etc. Kerala dominates the ginger production by producing about 33 percent of the total ginger produced in India. Ginger is available in the market in forms of oil, oleoresins, dry ginger, fresh ginger, ginger powder, ginger ale, ginger candy, ginger squash, ginger flakes, ginger beer, brined ginger and ginger wine etc. Light coloured ginger has traditionally been more priced for its suitable lemony aroma. Dark ginger has more heat and is favored for extraction purposes. Fresh ginger is used as a vegetable.

\section{Productivity comparison in monoculture andagroforestry system}

Correlation between ginger productivity in open and under shade has been evaluated by Amin MR et al. [6]. The yield of ginger was remarkably governed by the levels of shades compared. The bumper yield of ginger (12.42t/ha) was reaped from the treatment $(50 \pm 5 \%$ shade) when $50 \pm 5 \%$ sunlight was cut off. This yield was notably $19.65 \%$ higher even than the full sunlight conditions. The finding further established that ginger is scicophytic. On the other hand, as the levels of shades were increased further, the yield went down accordingly. Note that the yields were 75.05 and $48.84 \%$ yield obtained under full sunlight conditions and $70 \pm 5 \%$ of shades tested. So, these findings also pinpointed that the crop can tolerate up to $50 \pm 5 \%$ shade. It is interesting to note that most of the vegetative traits were positively momentous. Nonetheless, only four characters, e.g. number of rhizomes per plant, rhizome fresh weight per plant, rhizome dry weight per plant and number of fingers per plant with the leaf size were considerable at $5 \%$ altitude of possibility. Rahman [7] also harvested bumper yield of ginger (32.88t/ha) from the partial shade conditions while the least yield (18.75t/ ha) was recorded from the severe shaded conditions.

In India coconut + ginger system under rainfed conditions gave good returns as ginger performed well under shade where a few other crops could do as the yield of ginger was $11-27 \%$ higher than the open field [8]. In addition, variation in yield resulted from coalitions of shades of different crops with ginger was also noted by Singh $\mathrm{H}$ et al. [9] where the yield trend was in the rank: eucalyptus $>$ control $>$ poplar $>$ acacia.

\section{Factor affecting Ginger production in Agri-silviculture system}

Temperature: Ginger prefers the warm and humid climate but by gradual selection and long-term cultivation and domestication, it has adaptable to low temperature. When the temperature rises, germination is fast but sprouts are weak. In seedling stage, the suitable temperature is $22-28{ }^{\circ} \mathrm{C}$ and $25^{\circ} \mathrm{C}$ during rhizome enlarging stage [10].

Light: Ginger grows well in medium light intensity. It requires darkness in the germination stage. Moderate light in the seedling stage, and high light in the active growing stage. It does not affected by the day length [11]. Light compensation point of a single leaf is 20 to $30 \mu \mathrm{mol} \mathrm{m} \mathrm{m}^{-2} \mathrm{~s}^{-1}$ and its light saturation point is 660 to $820 \mu \mathrm{mol} \mathrm{m} \mathrm{m}^{-2} \mathrm{~s}^{-1}$. But the photosynthesis of the clump requires much higher light than of a single leaf [12].

Water: Ginger plant cannot endure the drought conditions. Soil humidity also affects the plant growth and yield. When the relative soil water content increased, the growth of ginger increased drastically but it cannot endure the water logging also [13]. Shading increased the root activity and chlorophyll contents and stomatic size of upper cuticulae of leaves but decreased the stomatal density and size of their lower cuticulae [14].

Seed size: The sprouting time of ginger was gradually earlier with the increasing of seed- size. The plant of big seed-ginger size grew vigorously at seedling stage. But practically too big or too small seed is not beneficial. The seed-ginger size of $75 \mathrm{~g}$, reached the highest yield of 2381.6t/ha; while the yields of ginger $100 \mathrm{~g}$, $50 \mathrm{~g}$, 25g treatments were 2166.8t/ha, 2051.8t/ha, 1733.4t/ha, respectively [15].

Spacing: Jaswal [3] observed the performance of ginger under rainfed conditions in pure stands and as intercrops with 5 -year-old poplar planted at three spacing viz. $5 \times 5 \mathrm{~m}, 5 \times 4 \mathrm{~m}$ and $5 \times 3 \mathrm{~m}$. The average illumination below the canopies was 53,46 and $38 \%$ of incident radiation, respectively. Plant height, tillers per plant and leaves per plant in ginger were significantly enhanced when intercropped. Among the all spacing $5 \mathrm{~m} \times 4 \mathrm{~m}$ were delineated as the best spacing for ginger production in the Agri-silviculture system.

Fertilizer: The uptake of NPK by ginger plants follows the model of 'Logistic equation'. However, the uptake proportion of NPK changed with growth and development of the plant [16], e.g. at the seedling stage, the uptake proportion of $\mathrm{K}$ was the highest, followed by $\mathrm{N}$ and $\mathrm{P}$, but the proportion of $\mathrm{K}$ uptake by the plant decreased at following stages. The ratios of NPK remains 11:1:16.1 in its whole life cycle.

Mulching straw: Mulching with straw in the ginger field increased the thickness of leaves, reduced the content of chlorophyll compared with shaded plants and increased the ability of plants to adapt to strong light. Leaves of ginger in unmulched field also changed but the photosynthetic rate was lower than that in mulched and shaded fields. Photosynthetic rate and its diurnal changes were almost the same under both mulching and shading conditions [17].

Canopy cover: Canopy cover of ginger was closely related to photosynthesis and its yield.

Furthermore, it depended on the canopy constitute. The unit area branches and LAI were over $150 / \mathrm{m}^{2}$ and $6 \mathrm{~m}^{2} / \mathrm{m}^{2}$ respectively in the higher yield canopy of the crop. Height, branches, LAI, canopy photosynthesis and yield had no remarked difference among the three canopies and all the three canopies obtained higher yield. Diurnal change of the canopy photosynthetic rate 
showed a typical single peak curve which was different from the double-peak curve from that of single leaf photosynthetic rate [18].

\section{Conclusion}

In the era of climate change, growing of tree to absorb the increasing level of carbon dioxide is the optional demand for cleaning the environment. Thus, agroforestry is the suitable practice in which we can take agricultural, horticultural and vegetation production in combination with the woody biomass. Ginger based agroforestry system is also a vital and production system so that we can improve the air, soil and nutritional quality of food. The Southeast Asia is the largest ginger producer and exporter in the world. India climatic condition is well favorable to grow the ginger. Indian ginger is the best in quality. It was unambiguously proved that ginger is a scicophytic crop performing remarkably performs well under partial shade than the open field. Hence its husbandry can be lucrative yet under such shade without inconsequently yield loss. Past studies pinpointed that the crop can be grown in such an agroforestry practices fruitfully.

\section{References}

1. FAO STAT Data (2017).

2. Spice Board of India (2016).

3. Jaswal SC, Mishra VK, Verma KS (1993) Intercropping Ginger and Turmeric with Poplar (Populus deltoides 'G-3' Marsh). Agroforestry Systems 22(2): 111-117.

4. Newman SM, Bennett K, Wu Y (1998) Performance of maize, beans and ginger as intercrops in Paulownia plantations in China. Agroforestry Systems 39(1): 23-30.

5. Valenzuela H (2011) Farm and Forestry Production and Marketing Profile for Ginger (Zingiber officinale). In: Elevitch CR (ed.), In:
Specialty Crops for Pacific Island Agroforestry. Permanent Agriculture Resources (PAR), Holualoa, Hawai, USA.

6. Amin MR, Ikbal TMT, Miah MM, Hakimand UMA, Amanullah ASM (2010) Performance of Ginger under Agroforestry System. Bangladesh Res Pub J 4(3): 208-217.

7. Rahman MA (2004) Growth and development of different vegetable and spices grown under multilayer agroforesrty system. MS Thesis, BAU, Mymensingh, Bangladesh.

8. Jayachandran BK, Ancy J, Babu P, Nizam SA, Mridula KR (1998) under the coconut tree: in India, ginger has it made in the shade. Kerala Agril Univ Kerala India. Agroforestry today 10(3): 16-17.

9. Singh H, Gurbachan S, Singh G (2001) Performance of turmeric in association with multipurpose tree species. Central Soil Salinity Res Ins Karnal, Haryana, India App Biol Res 3(1-2): 57-60.

10. Xizhen A, Zhenxian Z, Shaohui W (1998) Effect of temperature on photosynthetic characteristics of ginger leaves. China Veg 3: 1-3.

11. Zhenxian Z, Xizhen A, Qui Z (2000) Studies on the diurnal changes of photosynthetic efficiency of ginger. Acta Hort Sinica 27: 107-111.

12. Dewan Z, Kun X, Liping C (1991) Study on photosynthetic characteristics of ginger. Acta Hort Sinica 18: 55-60.

13. Kun X (1999) The influences of mulching with straw on the field microclimate and ginger growth. China vegetables 5: 5-8.

14. Xu K, Zou Q, Zhao Y (2003) Effects of soil water stress and shading on growth characteristics of ginger. Ying Yong Sheng Tai Xue Bao 14(10): $1645-1648$

15. Wang G, Xu R, Zhang Y (2003) Effect of seed Ginger size on the growth and yield of Ginger. China Vegetables 1: 13-15.

16. Xu K, Limei K, Zhao D (1992) Uptake and distribution of NPK by Ginger plants. Shandong Agricultural sciences.

17. Xu K, Li M (2000) Effect of mulching with straw on the photosynthetic characteristics of Ginger. China Vegetables 2: 18-20.

18. Xu X, Xu K, Xizheng A, Liping C, Zhenxian Z (1996) Study on relationship between canopy, canopy photosynthesis and yield formation in ginger Journal of Shadong Agricultural University, China.

\section{Your next submission with Juniper Publishers will reach you the below assets}

- Quality Editorial service

- Swift Peer Review

- Reprints availability

- E-prints Service

- Manuscript Podcast for convenient understanding

- Global attainment for your research

- Manuscript accessibility in different formats

( Pdf, E-pub, Full Text, Audio)

- Unceasing customer service

Track the below URL for one-step submission https://juniperpublishers.com/online-submission.php 